\title{
Geospatial modeling of the impact of sea level rise on coastal communities: application of Richmond, British Columbia, Canada
}

\author{
Abdulahad Malik ${ }^{1} \cdot$ Rifaat Abdalla ${ }^{2}$
}

Received: 13 July 2016/ Accepted: 14 July 2016/Published online: 4 August 2016

(C) Springer International Publishing Switzerland 2016

\begin{abstract}
Sea Level Rise (SLR) above the Mean Sea Level (MSL) may pose a substantial risk to coastal regions. This research investigates the possible impact of climate change and sea level rise in coastal areas. It locally analyzes the impact of sea level rise on Richmond, British Columbia, Canada. A model of Potentially Inundated Areas, based on a digital elevation model (DEM) was created, manipulated and processed in ArcGIS. Through this model, the impact of sea level rise was assessed on the surface area, residential areas, and a number of buildings, the number of dwellings, road network, and population. After the susceptible areas were delineated, it was estimated that at worst case scenario of $4 \mathrm{~m}$ sea level rise will impact Richmond by losing 46 percent of its total surface area, $462 \mathrm{~km}$ of road network will be under water, 637 buildings will be affected, $15 \mathrm{Sq}$. $\mathrm{km}$ of residential areas will be under water, and 30,000 houses will be affected. As a result, 89,000 people in the city will be displaced.
\end{abstract}

Keywords Sea level - Environmental impact - Climate change · Digital elevation model (DEM) - Modeling · Visualization

Rifaat Abdalla

rmabdalla@kau.edu.sa

Abdulahad Malik

mabdulahad@hotmail.com

1 Department of Geomatics, Waterloo University, Waterloo, Canada

2 Department of Hydrographic Surveying, King Abdulaziz University, Jeddah 21589, Saudi Arabia

\section{Introduction}

It was a major event, officially named the "2004 Indian Ocean Earthquake and tsunami”, that brought severe devastation to the shores of Indonesia and was regarded as the deadliest tsunami in the history of humankind with 200,000 deaths. Other such catastrophic events include the Katrina Hurricane, which affected large parts of New Orleans. More recently the March 2011 tsunami in Japan also brought havoc to the coastal regions of Japan and transformed the areas forever.

The Intergovernmental Panel on Climate Change (IPCC), which is regarded as the most authoritative scientific body on climate change and associated impacts and vulnerabilities, projects the global sea level rise to be $18-59 \mathrm{~cm}$ higher by 2100 . Such rise of the sea would add to the storm surge levels and exacerbate flooding. Had the sea level been higher when the above-mentioned tsunamis occurred, the water would have penetrated even further inland and the damage could have been even greater.

The increase in the sea level as a result of climate change will affect many coastal areas and inundate low-lying regions. Additionally, research has established the fact that with the rise in sea level and an increase in global temperatures, the coastal regions will experience more storm surges in the form of hurricanes and cyclones. Considering world's human populations, infrastructure, and economic activities are concentrated along coastlines; these are each highly vulnerable to any significant change in water levels.

Many researchers have attempted to study the sea level rise and its impacts on the coastal areas and the infrastructure associated with it. Such studies are extremely important in order to develop informed policy making related to climate change in general and seal level rise in particular. One such research was undertaken by $\mathrm{Li}$ et al. 
(2009) developed GIS methods to assess and visualize the global impacts of potential inundation based on a global sea level increase of $1-6 \mathrm{~m}$.

Although few researchers have studied global impacts of sea level rise using GIS, many researchers have studied the impact at regional and local levels. Gravelle and Mimura (2008) examined the impacts of sea level rise and storm surge in Fiji Islands, El-Nahry and Doluschitz (2010) analyzed the impacts of climate change on the coastal zone of the Nile Delta, Al-Jeneid et al. (2008) examined the impacts of sea level rise in the Kingdom of Bahrain, Natesan and Parthasarathy (2010) analysed the potential impacts of sea level rise along the coastal zone of Kanyakumari District in Tamilnadu, India, Marfai and King (2008) examined the vulnerability implications of coastal inundation due to sea level rise for the coastal zone of Semarang city, Indonesia, and finally Kuleli et al. (2009) developed a city based assessment of sea level rise for the Turkish Coastal Zone.

In this paper, the sea level rise impact on the coastal areas of Richmond, British Columbia was analyzed through the use of GIS and geospatial analysis tools.

\section{Objectives}

The main objective of the research is to analyse and assess the regional impact of climate change and sea level rise in Richmond British Columbia. The framework to achieve the objectives includes:

1- Understanding the environmental process that contribute to sea level rise, in form of natural atmosphere and solar energy/radiation balance and the link between solar radiation, atmosphere, and greenhouse effect. In addition to how the alteration of atmosphere and solar energy/radiation balance may affect the anthropogenic activities and the link between global warming and sea level rise and their future projections.

2- Reviewing the use of GIS methodologies in sea level rise scenarios and investigating data and processing requirements for SLR modeling.

3- Generating a GIS simulation model to study the impacts of one to 4-m seal level rise on Richmond, British Columbia, Canada.

\section{Literature review}

Geographical Information System (GIS) deals with describing, explaining, and predicting of patterns and processes at geographical scales. It is a science, technology, a discipline, and an applied problem-solving methodology (Longley 2005). It uses high-powered graphic and processing tools that are equipped with procedures and applications for inputting, storing, analyzing, and visualizing geo-referenced information. It also provides a great advantage of having a graphic database of geo-referenced or spatial information which is linked to a descriptive database (Azaz 2010). Since humans have the tendency to learn more effectively through visual means, GIS provides necessary stipulations to analyze the problem through visual as well as tabular means.

Over the years GIS has shown great potential in its application and problem-solving capabilities in many different sectors such as Health, Business, Environment, Military, Natural Resources, and Natural Hazards including flooding, Earth quakes, forest fires, and landslides. Moreover, GIS has been extensively used to study and analyse the spatial extent and impacts of sea level rise. GIS is, therefore, important and effective for simulating different hazard scenarios related to sea level rise. Through these scenarios, preventive measures can be taken by the authorities to prevent human and infrastructural loss.

\section{Sea level rise and GIS methods}

The following section, therefore, will review several methodologies used by researchers to study sea level rise globally and regionally.

There are several studies which have developed and explored many different techniques and methods to study the impacts of sea-level rise on the coastal regions. Although there are some studies which have explored the impact of sea level rise globally, the majority of the research, however, deals at regional and small geographical scale. This can be due to various complexities involved when studying the whole globe. The overwhelming data can be one issue; other reasons can be the difference in the dynamics of natural processes around different parts of the world. The availability and the limitation of data can also be another reason.

Some of the studies that analyzed the global impact of seal level rise include $\mathrm{Li}$ et al. (2009), Nicholls et al. (1999), Nicholls (2002, 2004), Nicholas and Tol (2006), Weiss and Overpeck (2003), Dasgupta et al. (2009).

Li et al. (2009) developed a comprehensive global model to analyse and visualize the impacts of sea level rise. The prominent feature of their research was to locate the potentially inundated area, the spatial extent of inundated area, type of land-cover being affected, and the effects on the population. The methods used by Li et al. (2009) were developed by Weiss and Overpeck (2003). The DEM was the foundation for their analyses. In the first step raster, cells adjacent to the ocean were selected. From these selected cells, cells with the elevation at or below the 
projected sea level rise increment were extracted. Selected cells were then converted to the ocean layer and thus the inundation zones from this layer were generated. Next, the area for the inundated zones was calculated using the formula developed by Bjorke and Nilsen (2004). The results showed that with $1-\mathrm{m}$ increase area of 1.055 million $\mathrm{km}^{2}$ was under water while at $6 \mathrm{~m}$ the area is increased to 2.193 million $\mathrm{km}^{2}$. The population at risk due to potential inundation ranges from 107.9 million people at $1 \mathrm{~m}$ to 431.4 million people at $6 \mathrm{~m}$.

There were, however, a few limitations in the methodology. The first limitation was that the method did not take into consideration the pressure of sea level rise on high water level which is important to compute accurate flood risk maps (Anthoff et al. 2006). The second limitation was that the existing protections, such as dikes were not taken into account in the methods (Tol et al. 2006; McGranahan et al. 2007). Lastly, the use of uniform sea level rise ignores the fact that changes in sea level do not occur uniformly around the world IPCC (2007). The economic impacts were also not part of the analyses.

Many studies have analyzed the impacts of sea-level rise on the coastal areas at a regional scale. Gravelle and Mimura (2008) examined the impacts of sea level rise and storm surge in Fiji Islands, El-Nahry and Doluschitz (2010) analyzed the impacts of climate change on the coastal zone of the Nile Delta, Al-Jeneid et al. (2008) examined the impacts of sea level rise in the Kingdom of Bahrain, Natesan and Parthasarathy (2010) analysed the potential impacts of sea level rise along the coastal zone of Kanyakumari District in Tamilnadu, India; Marfai and King (2008) examined the vulnerability implications of coastal inundation due to sea level rise for the coastal zone of Semarang city, Indonesia, and finally Kuleli et al. (2009) developed a city based assessment of sea level rise for the Turkish Coastal Zone.

Gravelle and Mimura (2008) developed a model which not only presented the impacts of the sea-level rise on the coastal areas but it also represented the areas which would be affected due to storm surges from sea level rise. The model was developed in three stages, in the first stage design water level components were created to show possible flooding and inundation around the coastline based on the sea level rise and storm surge scenario. The layer was generated from the tidal information and the storm surge scenarios were created from the residual water levels before and after the storm and from the tide gauges. In the second step, based on the IPCC projections, sea level rise values were added to the design water level layer. Finally using ArcGIS, the DEM, and the DWL layer was overlaid to show the extent of the inundation.

The results not only showed permanently inundated areas but also presented the areas that were affected by the storm surge pressure. The final output showed the high-risk areas based on various different scenarios. The major limitation of the following study was the results were generated at a very broad scale, in a sense that only highrisk areas were identified. The areas were not quantitatively assessed to produce tables or graphs showing the impact on land, infrastructure, and population.

El-Nahry and Doluschitz (2010) used GIS to determine the impacts of sea level rise on the on the Nile Delta. Their analyses were mainly concerned about the loss of land and alteration of soil characteristics on the delta. The analyses were heavily based on the field work through which the actual coastline was generated. Additionally, they used Landsat and ASTER imagery to derive digital elevation model and to conduct change detection for the coastline. Sea level rise scenarios were then generated using quadratic equation as a sum of global sea level rise, regional oceanic effects, and vertical land movement.

$\mathrm{Sr}, \mathrm{t}=\mathrm{Sg}, \mathrm{t}+\mathrm{So}, \mathrm{t}+\mathrm{Vt}$

where $\mathrm{Sr}, \mathrm{t}=$ relative $\mathrm{SLR}$ in year $\mathrm{t}(\mathrm{m}), \mathrm{Sg}, \mathrm{t}=$ global SLR in year $\mathrm{t}, \mathrm{So}, \mathrm{t}=$ regional sea level change induced by oceanic changes in year $\mathrm{t}(\mathrm{m}), \mathrm{V}=$ vertical land movement (m/year), and $\mathrm{t}=$ number of years in the future (base year 1990).

Through the above methodology, three sea level rise scenarios were created including $1 \mathrm{~m}$ rise, $1.5 \mathrm{~m}$ rise, and $2 \mathrm{~m}$ rise. With $1 \mathrm{~m}$ rise area of $6900, \mathrm{~km}^{2}$ would inundate which will include cropland, wetland, and fish ponds representing $28.93 \%$ of the total area of the Nile Delta. At $2 \mathrm{~m}$ rise area of $8425, \mathrm{~km}^{2}$ will be lost representing $35.33 \%$ of the total Delta area. Finally, at $3 \mathrm{~m}$ rise the 121 , $106 \mathrm{~km}^{2}$ area will be lost representing $50.78 \%$ of the total area of the Nile Delta.

Al-Jeneid et al. (2008) quantitatively assessed the impact of sea level rise on Bahrain. To accomplish their goals, the researcher integrated the use of Remote Sensing and GIS. As the first step in their methodology, they used the QuickBird satellite imagery to classify the image using unsupervised classification algorithm. Through the classification process and field work to enhance the results a land-use-land-cover map was created. Next, a high-resolution DEM $(5 \times 5 \mathrm{~m})$ was developed using the contours, height, and Bathymetry points. The contours, on the other hand, were manually digitized. Using the elevation points from the DEM and projections from IPCC, sea level rise scenarios were created. The scenarios were divided into three parts: low $(0.5 \mathrm{~m})$ moderate $(1 \mathrm{~m})$, and high $(1.5 \mathrm{~m})$.

Natesan and Parthasarathy (2010) analysed the potential impacts of sea level rise along the coastal zone of Kanyakumari District in Tamilnadu, India. The methodology in the following study was divided into five parts. In the first part, GIS data was generated by digitizing the study boundary and coastal villages. In the second step the 
contours were and in the third part of the methodology, DEM was created. The DEM was generated using the elevation points and interpolation method. Next, using the DEM inundation zones were derived by setting the value $0.5 \mathrm{~m}$ and $1 \mathrm{~m}$ for the sea level rise scenario. Finally, the inundated areas were overlaid with land-use, village, tourism, and sensitive areas data to analyse the impact.

Most of the studies used the digital elevation model (DEM) in one form or another to derive the inundated zones, the approach to developing and exploit the DEM varied. For example, El-Nahry and Doluschitz (2010) and Al-Jeneid et al. (2008) developed their own DEM designed particularly to analyze the sea level rise. Al-Jeneid et al. (2008) produced the DEM using high-resolution contours, 6000 spot height points, and bathymetry data containing 20,000 points of the sea floor. The result was a $5 \times 5 \mathrm{~m}$ DEM model which subsequently was used to generate a sea level rise model. El-Nahry and Doluschitz (2010) on the other used DEM derived from ASTER imagery but also incorporated the field data into the DEM to improve the horizontal and vertical accuracy. However, in these two studies, it was noted, a separate GIS water layer was not incorporated into the methodology and simply the DEM values which fell below the mean sea levels were considered as water. Gravelle and Mimura (2008) on the other hand used the DEM for land elevation only; the water layer was separately generated from tide gauges and then overlaid on the DEM to analyze the extent of sea level. Natesan and Parthasarathy (2010) developed a different approach than the above studies. They used the DEM to create inundated zones only and in order to assess the impact and extent of sea level rise, the inundated zones were simply overlaid on the GIS layers such as land-use, villages, tourism, and sensitive areas in the coastal region.

Finally, Li et al. (2009) created a global model to assess the impact of sea level rise. In this study, similar to all the above-mentioned studies, DEM was used as the foundations to generate a sea level rise impact model. The modelling approach in this study, however, differed slightly. Unlike, other studies, Li et al. (2009) considered the adjacency to the water body and as their first step selected DEM cells that were adjacent to the water layer; based on these selected cells, cells with elevation at or below projected sea level rise were then chosen to create an inundated zone.

\section{Case Study of Richmond, British Columbia, Canada}

The city of Richmond is located in the South Western part of the Province of British Columbia (N $4910^{\prime}$ and W $1238^{\prime}$ ) between the two arms of Fraser River and is part of the Greater Vancouver area. It has an area of $129 \mathrm{~km}^{2}$ and consists of 17 islands (City of Richmond 2009). It is mostly a low- lying, flat area with the height of apex being $335 \mathrm{~m}$ higher than the mean sea level (City of Richmond 2009). The city is connected with the Regional Transportation Link; the Vancouver International Airport is also located in Richmond and has two sea ports, Fraser Port, and Stevenson Fishing Port.

The population as of 2009 BC Stats estimate was 193,555 and the projected population in 2021 is 225,000 (City of Richmond 2009). There were 125, 000 jobs in 2009 with major industries being high tech companies, retail, aviation, transportation, tourism, service, manufacturing, and agriculture (City of Richmond 2009). There were 100 parks (1500 acres) including the 320 acres Lona Island Regional Park; $80 \mathrm{~km}$ system of interconnecting dyke trails, cycling routes, and walkways, eight community centres, two arenas, eight rinks, two indoor aquatic centres, and two outdoor pools (City of Richmond 2009). Table 1 is showing population estimates for the City of Richmond. Table 2 is presenting the percentage of the number of units in the City of Richmond.

The city of Richmond is divided into thirteen neighbourhoods. Out of these neighbourhoods, the City Centre and Steveston are the most populous neighbourhoods (Table 3). Table 4 is showing the land-use crop production for Richmond in 2006. According to the 2006 Census, these neighbourhoods contained 61,430 private dwellings, out of which single detached account for 41.3 percent of the housing stock followed by low and high rise apartment units (30.7 percent), row house units ( 22 percent), and semi-detached or two family dwellings units accounted for 2.1 percent (Table 1 ).

The distribution of these dwellings in terms of their spatial location is shown in Table 3.

Agriculture an important part of Richmond's history and a significant portion of the city's land area is used for agricultural activities. Agriculture plays an important role in

Table 1 Population estimates by neighbourhoods Source: City of Richmond 2011

\begin{tabular}{lrr}
\hline Neighbourhood & 2001 & 2006 \\
\hline Bridgeport & 3081 & 2995 \\
East Richmond & 3272 & 3410 \\
Hamilton & 4146 & 4610 \\
West Cambie & 5532 & 6750 \\
East Cambie & 10,508 & 10,400 \\
Shellmont & 10,739 & 10,000 \\
Thompson & 14,431 & 15,450 \\
Blundell & 17,529 & 17,500 \\
Broadmoor & 22,653 & 22,350 \\
Steveston & 22,340 & 24,105 \\
City Centre & 33,044 & 38,610 \\
Seafair & 16,091 & 16,165 \\
Airport & 736 & 770 \\
\hline
\end{tabular}


Table 2 Number of units by housing type Source: City of Richmond 2011

\begin{tabular}{lcl}
\hline Number of units by housing type & Units & $\%$ \\
\hline Single-detached house & $\mathbf{2 5 , 3 8 5}$ & $\mathbf{4 1 . 3}$ \\
Apartment, building that has fewer than five storeys & $\mathbf{1 5 , 1 6 0}$ & $\mathbf{2 4 . 6}$ \\
Row house & 11,805 & 19.2 \\
Apartment building that has five or more storeys & 3760 & 6.1 \\
Apartment, duplex & 3230 & 5.2 \\
Semi-detached house & 1840 & 2.9 \\
Movable dwelling & 235 & 0.382 \\
Other single-attached house & 10 & 0.0162 \\
Total number of occupied dwellings by structural type of dwelling & 61,430 & 100.0
\end{tabular}

Bold values indicate the dominance percentage of housing units types in Richmond
Table 3 Total number of occupied private dwellings by planning area Source: City of Richmond 2011

\begin{tabular}{lc}
\hline Planning area & Total dwellings \\
\hline Bridgeport & 850 \\
East Richmond & 1070 \\
Hamilton & 1410 \\
West Cambie & 2015 \\
East Cambie & 3090 \\
Shellmont & 3145 \\
Thompson & 5250 \\
Blundell & 5650 \\
Broadmoor & 7460 \\
Steveston & 8915 \\
City Centre & 16,535 \\
Airport & 290 \\
Seafair & 5580 \\
\hline
\end{tabular}

Table 4 Richmond's top crops in 2006 Source: City of Richmond 2011

\begin{tabular}{lccc}
\hline & Area (ha) & \% of Crops & \% of ALR \\
\hline Land Used in Crop Production-Top & 10 Crops & \\
Cranberries & 658 & $\mathbf{3 1 . 4}$ & 13.4 \\
Blueberries & 448 & $\mathbf{2 1 . 4}$ & 9.1 \\
Hay & 206 & 9.8 & 4.2 \\
Alfalfa & 163 & 7.8 & 3.3 \\
Oats & 157 & 7.5 & 3.2 \\
Potatoes & 138 & 6.6 & 2.8 \\
Strawberries & 42 & 2.0 & 1.0 \\
Cabbage & 37 & 1.8 & 0.8 \\
Squash, pumpkins & 34 & 1.6 & 0.7 \\
Sweet Corn & 18 & 0.8 & 0.3 \\
Total & 1901 & 90.7 & 38.8 \\
\hline
\end{tabular}

Bold values indicate the major crops in Richmond according to 2006 data
Table 5 Affect of 1-4 m SLR on building, residential areas, and road network

\begin{tabular}{llll}
\hline $\begin{array}{l}\text { Sea level } \\
\text { rise }(\mathrm{m})\end{array}$ & $\begin{array}{l}\text { Non-Residential } \\
\text { Buildings }\end{array}$ & $\begin{array}{l}\text { Residential } \\
\text { Area }\left(\mathrm{km}^{2}\right)\end{array}$ & $\begin{array}{l}\text { Road } \\
\text { Network }(\mathrm{km})\end{array}$ \\
\hline 1 & 113 & 0.53 & 54 \\
2 & 165 & 1.18 & 102 \\
3 & 349 & 7.29 & 242 \\
4 & 637 & 15 & 462 \\
\hline
\end{tabular}

the local and regional economy, as well as a being a major land use in the city. Approximately 116 acres of Richmond's land base, or 38 percent of the city, is within the agricultural land reserve (ALR) (City of Richmond 2009) (Table 4).

Cranberry is the most dominant crop in Richmond, with almost 658 ha in production. Richmond's other top crops are outlined below:

Heritage is an important part of Richmond's history, it has been divided into eight major themes including: Aboriginal use, fishing sites, Cultural diversity, Stevenson, Agriculture, Transportation and Early Settlement Areas.

Out of the different heritage themes, buildings have been the most common focus of heritage conservation. In the city's heritage inventory, there are 83 identified heritage buildings or sites in Richmond. Two of the identified heritage buildings have received Federal designation; this includes Gulf of Georgia Cannery and Britannia Heritage Shipyard (City of Richmond 2009). Additionally, there is fifteen city designated heritage sites, eight of which are owned by the city while the other seven are privately owned (City of Richmond 2009).

Richmond's history is also represented by diverse other resources, this includes railway tracks, telephone poles, sloughs, festivals, archaeological sites, and landscapes. Currently, there are 110 heritage trees and 73 archaeological sites (City of Richmond 2009). Tables 5 and 6 are respectively showing the impact of SLR levels from 1-4 m and the values of the impact on Richmond. 
Table 6 Impact of sea level rise on residential areas in various neighbourhoods

\begin{tabular}{llllll}
\hline & Total residential area $\left(\mathrm{km}^{2}\right)$ & $1 \mathrm{~m}$ & $2 \mathrm{~m}$ & $3 \mathrm{~m}$ & $4 \mathrm{~m}$ \\
\hline Bridgeport & 0.51 & - & - & - & 0.41 \\
Cambie & 1.66 & - & - & - & 1.0 \\
City Centre & 3.45 & - & 0.14 & 0.22 & 0.36 \\
Broadmoor & 5.22 & 0.53 & 0.53 & 1.0 & 1.7 \\
Blundell & 4.0 & - & - & 2.7 & 3.5 \\
Stevenson & 4.0 & - & - & 2.5 & 3.42 \\
Seafair & 3.6 & - & - & - & 2.7 \\
Thompson & 2.1 & - & 0.1 & 0.8 & 1.7 \\
Airport & 0.3 & - & 0.1 & 0.27 & 0.3 \\
\hline
\end{tabular}

Table 7 Area lost from 1 to $4 \mathrm{~m}$ sea level rise

\begin{tabular}{llr}
\hline Sea level rise $(\mathrm{m})$ & Area $\left(\mathrm{km}^{2}\right)$ & $\%$ \\
\hline 1.0 & 8.3 & 6 \\
2.0 & 11.1 & 8 \\
3.0 & 33.9 & 26 \\
4.0 & 60 & 46 \\
\hline
\end{tabular}

\section{Methods and data}

The impact of SLR has been highlighted and analyzed through procedures followed to build the SLR scenarios and to assess the vulnerability of the coastal areas using GIS geoprocessing approaches. This research identifies vulnerable sectors, regions, and resources and assesses the degree of future risk posed by SLR in order to enhance the city's capacity to address the possibility of accelerated sea level rise. The methodological framework applied in the study can be divided into two sections; the first section deals with analyzing the impacted areas through spatial analysis, while the second part simulates the impact and presents the results in the form of simulation. The spatial analyses were carried out using ArcGIS while the simulation was generated using MicroDEM and Google Earth program.

\section{Delineating potential inundated areas}

In order to study and analyze the impact of potential sea level rise, it was necessary to create potentially inundated areas (PIAs). PIAs were created by manipulating the information present in the DEM. The methodological structure followed to create the inundated areas and to generate spatial results is shown in the flow chart below, Fig. 1.

\section{DEM processing}

The DEM provided by GeoBase had several sinks which presented negative values for the respective cells. These sinks which can be problematic for delineating basins and streams, needed to be removed to keep the integrity in the generated results. In order to overcome the sink problem, fill tool in ArcGIS was to remove the imperfections in the original DEM by converting the negative cell values into meaningful elevations.

\section{Raster calculator and reclassification}

Next, using the Map Algebra Expressions in raster calculator, desired cells were extracted in the form of new rasters. These new raster were generated using the elevation values of one to $4 \mathrm{~m}$. These newly extracted rasters were pivotal in generating the inundated areas.

The above-generated rasters consisted of cells with two values, 0 and 1.1 represented the cells that were of interest while 0 represented the remaining cells in the raster. Therefore, these rasters were then reclassified using the reclassification tool to reclassify the 0 value cells as No Data and thus the respective cells had null values. This process was repeated for all four rasters.

\section{Raster to polygon and sea level rise scenarios}

The reclassified raster were then converted to a polygon using raster to polygon tool in ArcGIS. This was done mainly because vector data is easier to manipulate and analyze than the rasters cells.

These newly generated shapefiles were then selected based on location. Selecting the shapefiles by location allowed selecting areas which touched the water boundary. This was done for all four shapefiles. Thus, the 1-m shapefile that touched the water boundary was 1-m sea level rise. The $2-\mathrm{m}$ sea level rise scenario was created by selecting the $2-\mathrm{m}$ areas that touched the water body plus $1 \mathrm{~m}$ SLR. The same procedure was repeated until 3 and 4-m sea level rise scenarios were generated.

\section{Spatial analyses of impacted areas}

Once the inundated zones/areas were created as described above, it was possible to analyze the impact on the study 


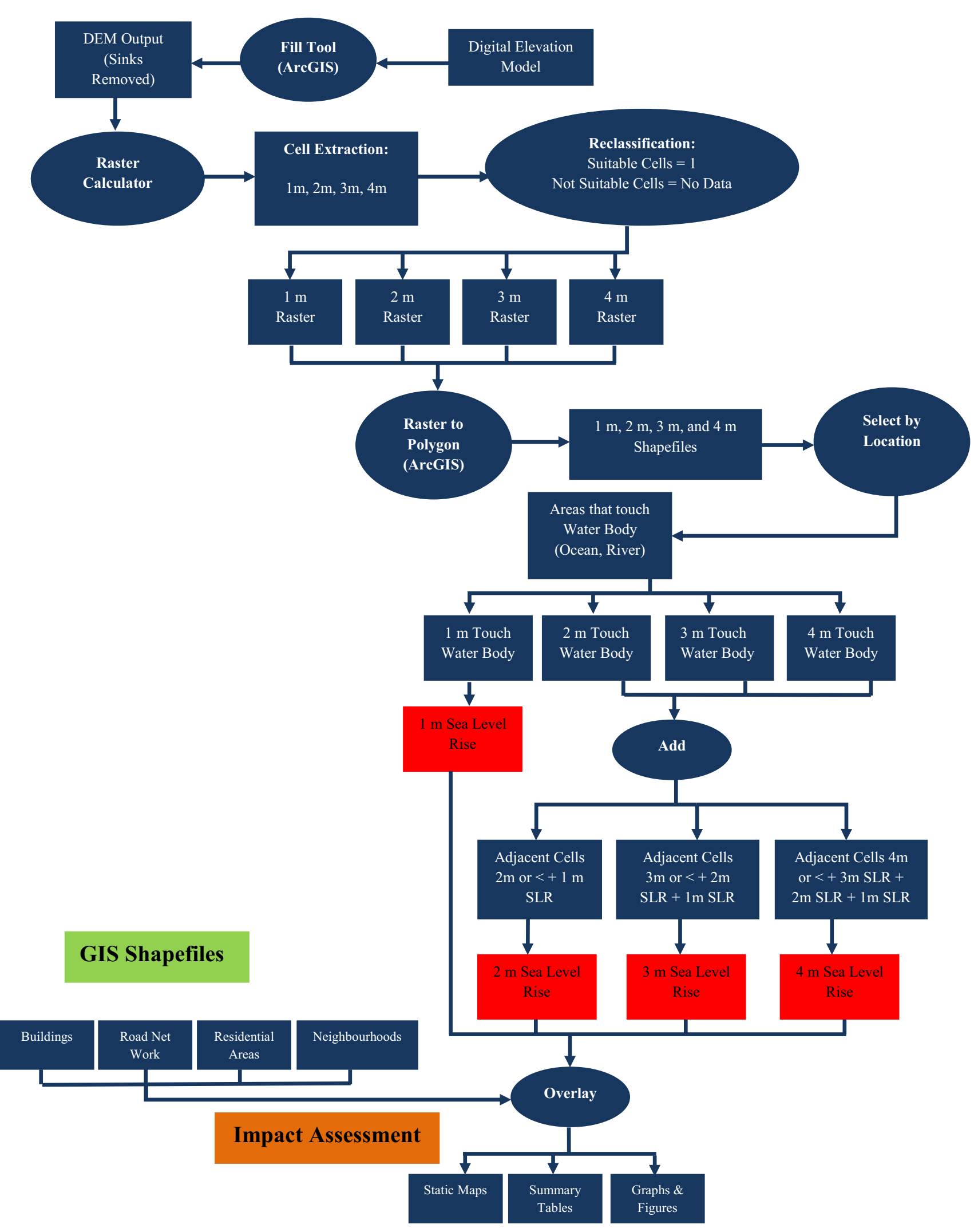

Fig. 1 Methodology flow chart 
area through spatial analysis. The impact assessment was done by overlaying the inundated layer generated in the previous section on the spatial data of interest. The Zonal Statistics Tool in ArcGIS was used for the overlaying analyses. Through this method, the impact on the overall area was analysed through different sea level rise scenarios. The analyses included impacts on land-use/land-type, residential areas, building footprints, parks, road network, dwellings, and population. Additionally, through basic statistical principles, the impact was approximated on the population in different neighbourhoods of the city. The results of the analyses are presented and discussed in the Results section.

\section{Affected population and dwelling approximation}

The data for population and number of dwellings in each neighbourhood were in the form of non-spatial data. In order to incorporate the population and dwelling information into the analysis, the approximation method was used. It was assumed that population and dwellings were evenly distributed throughout the residential areas. Through four different flood scenarios, the percentage of residential area lost was calculated and then multiplied with total population and residential dwellings to get the affected population and residential dwellings. The formula can be represented as follows:

Population affected $=\%$ of area lost through flooding

$(1 \mathrm{~m}, 2 \mathrm{~m}, 3 \mathrm{~m}, 4 \mathrm{~m}) \times$ total population

Dwellings affected $=\%$ of area lost through flooding

$(1 \mathrm{~m}, 2 \mathrm{~m}, 3 \mathrm{~m}, 4 \mathrm{~m}) \times$ total dwellings

\section{Visualizing potential inundated areas}

The propagation of potential inundation, as well as the probable impact of sea level rise on the natural and built-up environment, was depicted through the use of various geographical visualization methods. The static maps showing the extent of the damage were produced using ArcGIS while the simulation was generated through the use of MicroDEM and Google Earth programs.

\section{MicroDEM}

MicroDEM works with digital elevation models and has certain excellent capabilities related to terrain visualization and analysis. This program was created by Peter Guth, professor of Oceanography at the US Naval Academy. The flooding simulation was created using the aforementioned DEM.

The DEM was first processed so the land and water could be distinguishable. The display parametre was used to depict all elevation at $0 \mathrm{~m}$ (i.e., sea) blue and all higher elevations (i.e., land) as green, making the terrain easier to identify.

The simulation was created using the Drainage Tool, within which basin flooding functionality was used to set the flooding parameters. The parameters included the Reservoir Top which indicated the maximum height of the flooding; Low Level indicated the minimum flooding value, and interval which was the step increase in the flood level. The user has the option to generate still images or simulation. Additionally, various shapefiles, such as political boundaries, roads, and building footprints were also overlaid on to the DEM.

\section{Google Earth}

In order to generate Google Earth Simulation, MicroDEM was used to create 8.GIF images that depicted the sea-level rise ranging from 0.5 to $4.0 \mathrm{~m}$. The.GIF images represented the land as transparent while the water was represented with light blue colour. Each of the eight images was then exported in Google Earth and were adjusted using the North, East, South, and West coordinates and the rotation angle. Eventually, all the images were aligned properly on top of each other. All these images were stored in a folder created in the table of contents in Google Earth; the folder was then exported as a.KML file. Since animations in Google Earth are time-based, each image was assigned a time-span tag. Each image layer was assigned a year's worth of time with 2000 being the year of no sea level rise, $20010.5 \mathrm{~m}$ of sea level rise, and so until 2008 corresponded to $4 \mathrm{~m}$ of sea level rise. The exact date/time assigned to each image had to be sequential, and equal in length.

The editing session was saved and the file was re-opened in Google Earth to view the animation. The animation was recorded using HyperCam and the final animation was produced after editing in the Windows Movie Maker.

\section{Key assumptions}

The methodology used to create the inundated model was generated based on few assumptions; these assumptions are as follows:

- It was assumed the DEM portrayed accurate elevation information, although the vertical accuracy for the DEM was within $5 \mathrm{~m}$.

- The sea level rise scenarios were generated based on the water connectivity. Sea level rise can also impact the 
surface area through an increase in the levels of the water table; however, this factor was ignored in the methods.

- The dikes and current protective infrastructure on the coastal areas were not taken into consideration. Thus the model portrays a sea level rise which is continuous and does not come in contact with the protective infrastructure.

- Since no spatial data for the population and residential buildings was available, it was assumed that population and residential buildings are evenly distributed in the residential areas.

\section{Data sources}

\section{Geospatial data sources}

The Digital Elevation Model (DEM) for the Richmond area was instrumental in providing the foundations for analyzing the impact of sea level rise. The DEM was obtained from GeoBase database. The vertical content of the DEM is expressed in metres and can vary from 0 to $5959 \mathrm{~m}$ in Canada. The vertical accuracy of the DEM cells is within 5 $m$ of the true elevation. The coastlines, oceans, and estuaries at mean sea level are assigned an elevation value of 0 m. All mean high water level elevation values are with reference to the Canadian Vertical Geodetic Datum 1928 (CVGD28). Another relevant information is as follows:

Scale $=1: 50000$

Minimum Elevation $=0 \mathrm{~m}$

Maximum Elevation $=335 \mathrm{~m}$

Other Geo-Spatial data used in the analysis consist of administrative boundaries, Building Footprints, Road Network, Historical Sites, Parks, Water Bodies, Residential Areas, Railaway Tracks, Sport Fields and Wooded Areas. Additionally, neighbourhood data was generated by digitizing the information from the planning maps provided by the City of Richmond.

\section{Non-spatial data sources}

In addition to the above-mentioned spatial data, non-spatial data related to the population and residential buildings was also acquired. The population data was from census Canada; the data was of two types, one for the entire city and the other was each individual neighbourhoods. On the other hand, data related to dwellings in each neighbourhood was obtained from the City of Richmond official website.

\section{Results and discussion}

Sea Level Rise (SLR) above the Mean Sea Level (MSL) may pose a substantial threat to Richmond's coastal areas because of its low-lying physiographical setting and the infilling activities that have been carried out throughout the years. Critical infrastructures such as major roads, causeways, and many socioeconomic activities are concentrated in the coastal areas. These areas support various economic activities including hotels, airport, and industrial and commercial complexes. In addition, significant numbers of residential areas are also concentrated along the coastal areas. With an increase in the sea level, not only the areas along the coast will be affected but also the low-lying adjacent land will also be inundated.

The main objective of this research was to create potentially inundated areas using digital elevation model for Richmond, BC. Through these inundated areas, the impact was assessed qualitatively as well as quantitatively. The factors that were considered crucial in the impact assessment included surface area, neighbourhoods, the number of buildings, residential areas, the number of dwellings, and population. The impact of these factors was assessed using the available spatial-data. However, the data related to population and number of dwellings in each neighbourhood was in the form of non-spatial-data. Therefore, the impact on the population and dwellings were approximated using Eqs. 2 and 3. Population impact reported in was calculated by considering the assumption that population is evenly distributed in the whole city; therefore, the total city population was used as one of the variables in the equation. However, to assess the population impact in each neighbourhood, the assumption that population is evenly distributed in residential areas was considered.

To quantify and to visually analyse the impact of sea level rise on Richmond, BC, an inundated model using the Digital Elevation Model (DEM) shown in Fig. 2 was used.

Through this model, analysing the impact on the infrastructure such as roads, buildings, residential areas, population, and a number of dwellings were made possible. Once the inundated model was generated, it was overlaid on to the City of Richmond area to see the potential impact and to quantify the area lost due to the sea level rise. It was possible to visually represents the impact of sea level rise from 1 to $4 \mathrm{~m}$ while the quantitative information about the area under water in $\mathrm{km}^{2}$ was in Figs. 3, 5 and Table 7.

Next, through spatial analysis and using the Zonal Statistics functionalities in ArcGIS, the impact of sea level rise on buildings, residential areas, and road network was determined as shown in Table 8. The impact on buildings was represented through each individual building footprint while the impact on the residential area was represented in $\mathrm{km}^{2}$, and finally the impact on road network was presented in km (Figs. 4, 5, 6, 7, 8) which are showing the output of the spatial analysis conducted to determine the SLR.

Table 9 portrays overall scenarios of the sea level rise by taking into account the whole city. However, to analyze 


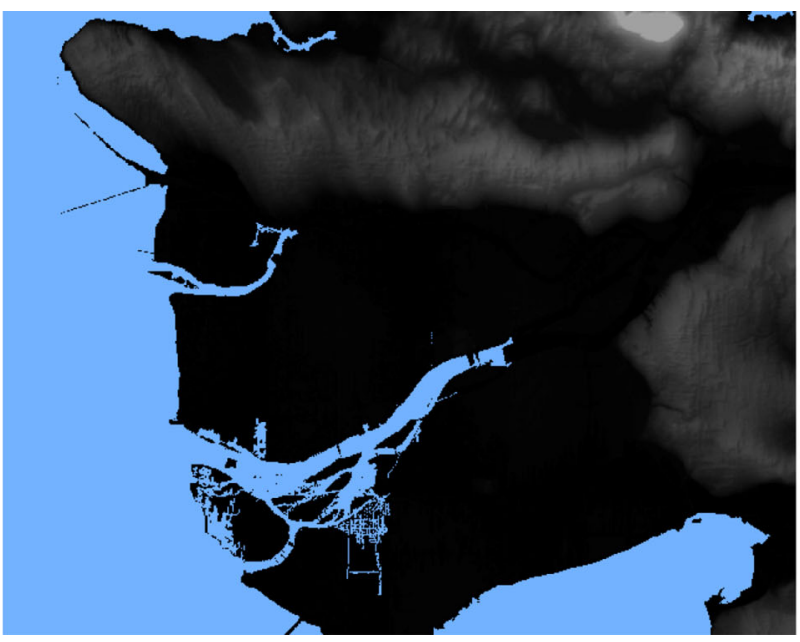

Fig. 2 Digital elevation model used to generate the inundated zones

the city in detail it was necessary to study each neighbourhood individually. The city of Richmond is divided into fourteen neighbourhoods as shown in Fig. 12.

Through Zonal statistic functionalities in ArcGIS, the neighbourhoods were spatially analyzed to determine the impact of sea level rise on their respective surface area (Table 10 and Fig. 12), residential areas in each neighbourhood and a number of buildings affected.

Lastly, by using Eqs. 2 and 3, the affect of sea level rise in the population (Table 9; Fig. 9) and dwellings in the residential areas (Table 10; Fig. 10) was determined. Since the major impact of sea level rise was observed at $4 \mathrm{~m}, 1-3$ $\mathrm{m}$ impact was ignored. However, they will briefly be discussed in the following section.

The detailed impact was analysed using four different scenarios that are discussed in below.

\section{Modeling scenarios}

\section{$1 \mathrm{~m}$ sea level rise scenario}

At $1 \mathrm{~m}$ rise, the impact on infrastructure, population and dwelling were minimal with $8.3 \mathrm{~km}^{2}$ area which accounts for about $6 \%$ of the total area is lost to sea level rise. In total $113(11 \%)$ buildings are impacted $0.53 \mathrm{Sq} . \mathrm{km}$ of a residential area, and $54 \mathrm{~km}$ of the road network in underwater. Broadmoor is the only neighbourhood in which the residential areas are affected with 0.53 sq. km $(10 \%)$ of residential impacted. The hard-hit neighbourhood in terms of area is East Richmond with 5.4 sq. $\mathrm{km}(14 \%)$ of area inundated, followed by Gilmore 1.2 sq. km (13\%), and Airport and Bridgeport 1.0 sq. $\mathrm{km}$ each, which accounts for 7 and $23 \%$ of the total area respectively. In terms of percentage of area lost, Bridgeport is the hardest hit neighbourhood. In total 113

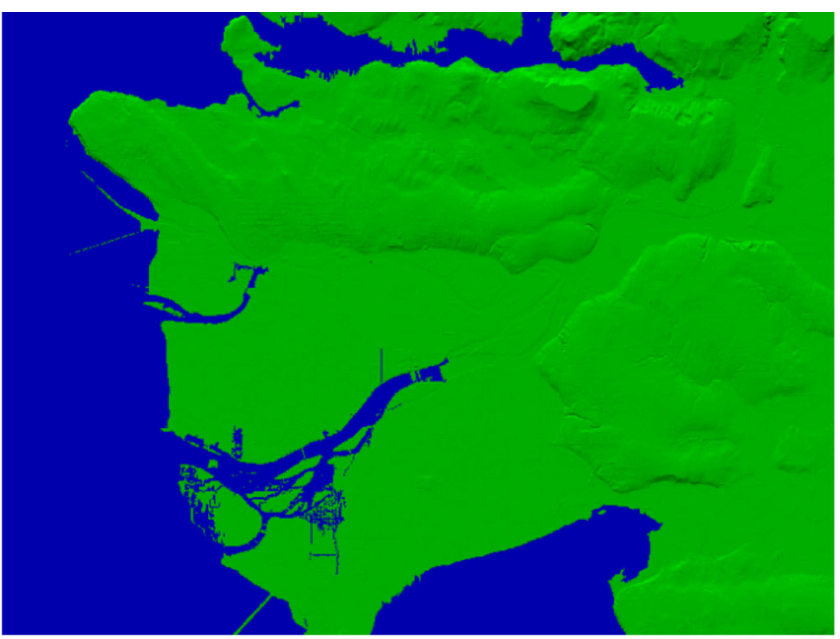

buildings are affected, out of which 54 are in Bridgeport $(29 \%), 34$ are in East Richmond (17\%), 12 are in Stevenson $(27 \%)$, and 4 are affected in Cambie neighbourhood $(3 \%)$. The $\%$ in brackets represents the total percentage of buildings affected in each neighbourhood.

\section{$2 m$ sea level rise scenario}

In addition to the above-mentioned scenario, at 2-m sea level rise $11.1 \mathrm{sq} . \mathrm{km}$ surface area of the city is lost, which accounts for $8 \%$ of the total area. $165(16 \%)$ buildings will be affected, out of which 62 are in Bridgeport, 38 in East Richmond, 18 in Airport, 14 in Stevenson, 13 in City Centre, 19 in Gilmore, 6 in Cambie, and 3 in Fraser Lands are affected. In addition to the area and number of buildings, $102 \mathrm{~km}$ of Road Network is under water and $1.18 \mathrm{sq} . \mathrm{km}$ of the Residential area with 15,484 people affected. Similar to the above scenario East Richmond neighbourhood lost the greatest amount of area (7.87 Sq. km) followed by Airport, Gilmore, and Bridgeport neighbourhoods with 2.7, 1.5, and $1.12 \mathrm{Sq} . \mathrm{km}$ respectively. In addition to the residential area of Broadmoor, at $2 \mathrm{~m}$ rise residential areas of Airport, Thompson, and City Centre with $0.1,0.1$, and 0.14 Sq. km respectively is also affected.

\section{$3 \mathrm{~m}$ sea level rise scenario}

Sea level rise increase at $3 \mathrm{~m}$ will have a devastating effect on the city with 33.9 sq. $\mathrm{km}$ of surface area under water, accounting for $26 \%$ of the total area. Overall, more neighbourhoods, their residential areas, buildings, and roads are affected. The buildings affected increase from 165 at $2 \mathrm{~m}$ to 349 at $3 \mathrm{~m}$ sea level rise. The residential areas affected increase from 1.18 to $7.29 \mathrm{sq}$. $\mathrm{km}$, representing $27 \%$ of the total residential areas with 50,324 people 


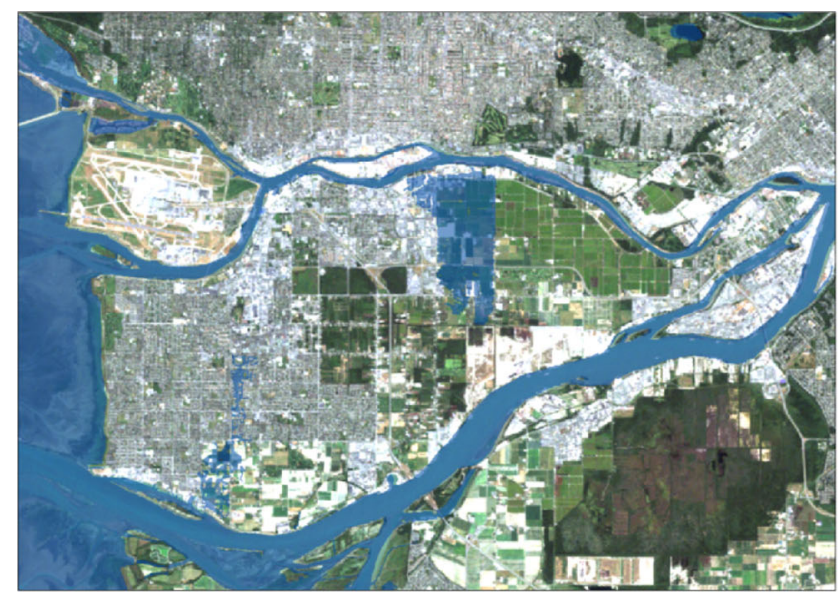

A $1 m$ Sea Level Rise

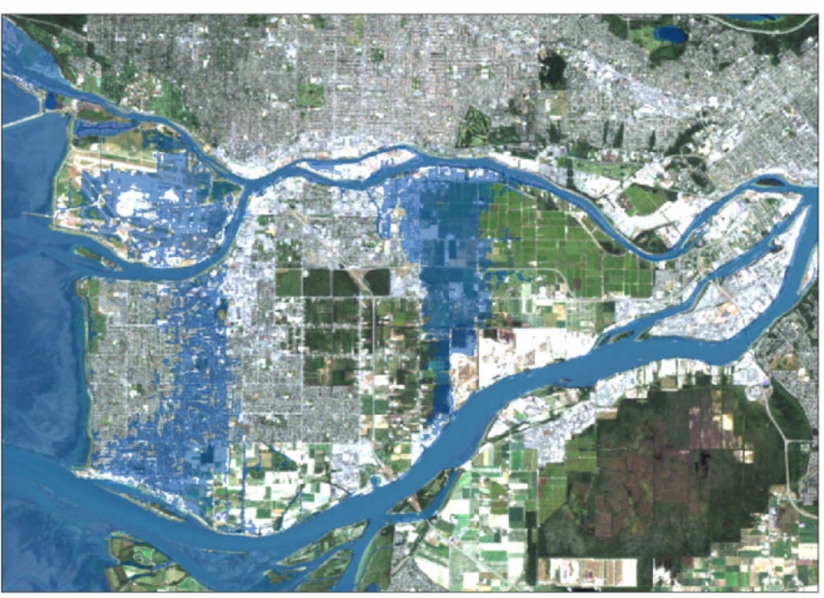

C $3 \mathrm{~m}$ Sea Level Rise

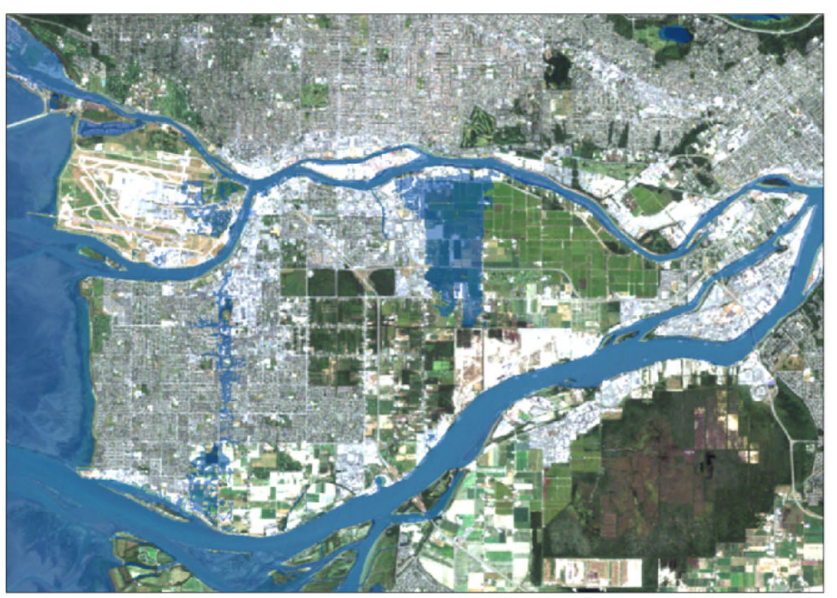

B $2 \mathrm{~m}$ Sea Level Rise

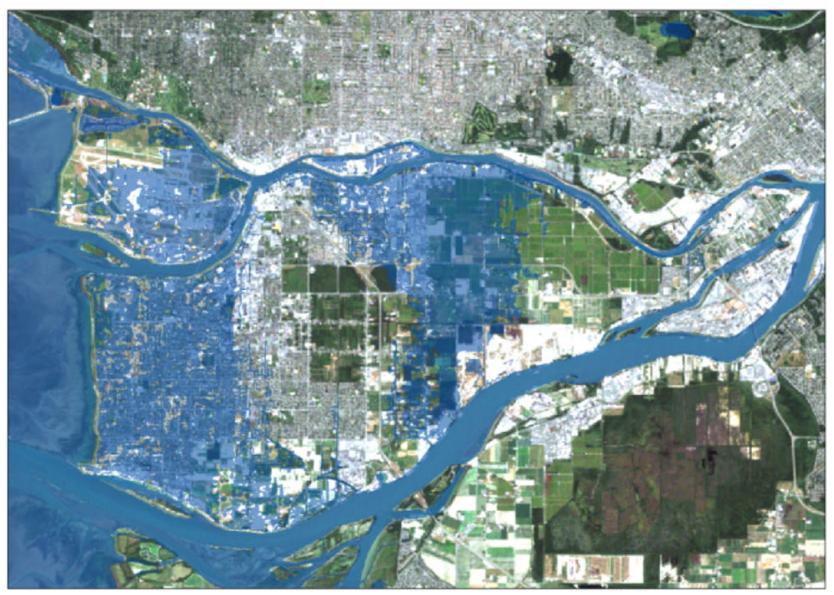

D $4 \mathrm{~m}$ Sea Level Rise

Fig. 3 Sea level rise scenarios from 1 to $4 \mathrm{~m}$

Table 8 Number of nonresidential buildings affected in various neighbourhoods with 1 to $4 \mathrm{~m} \mathrm{SLR}$

\begin{tabular}{lrrrrr}
\hline & Total non-residential buildings & $1 \mathrm{~m}$ & $2 \mathrm{~m}$ & $3 \mathrm{~m}$ & $4 \mathrm{~m}$ \\
\hline Bridgeport & 185 & 54 & 62 & 106 & 177 \\
Cambie & 124 & 4 & 6 & 32 & 84 \\
Fraser lands & 28 & 0 & 3 & 3 & 9 \\
East Richmond & 195 & 34 & 38 & 66 & 107 \\
Shellmont & 60 & 0 & 0 & 0 & 4 \\
City Centre & 145 & 0 & 13 & 27 & 69 \\
Broadmoor & 20 & 0 & 0 & 4 & 8 \\
Blundell & 12 & 0 & 1 & 9 & 10 \\
Gilmore & 55 & 9 & 10 & 19 & 39 \\
Stevenson & 44 & 12 & 14 & 37 & 42 \\
Seafair & 12 & 0 & 0 & 0 & 12 \\
Thompson & 22 & 0 & 0 & 12 & 20 \\
Airport & 58 & 0 & 18 & 34 & 56 \\
\hline
\end{tabular}




\section{Total Suface Area lose to Sea Level Rise}

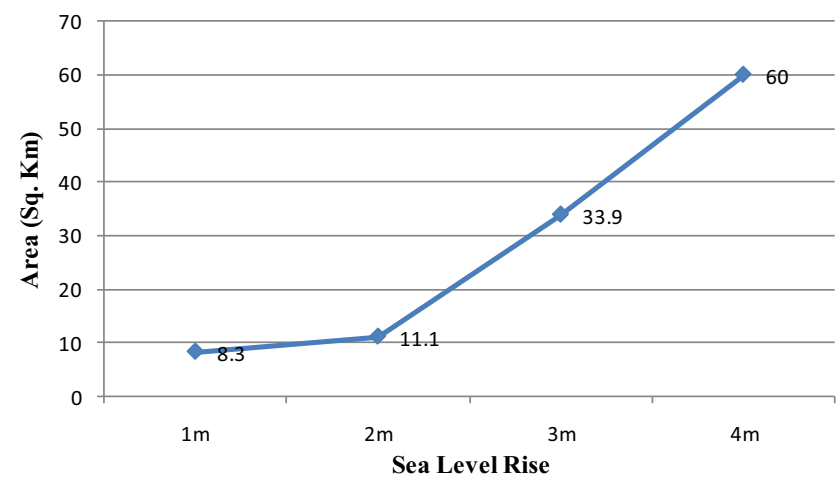

Sea level Rise and impact on Population

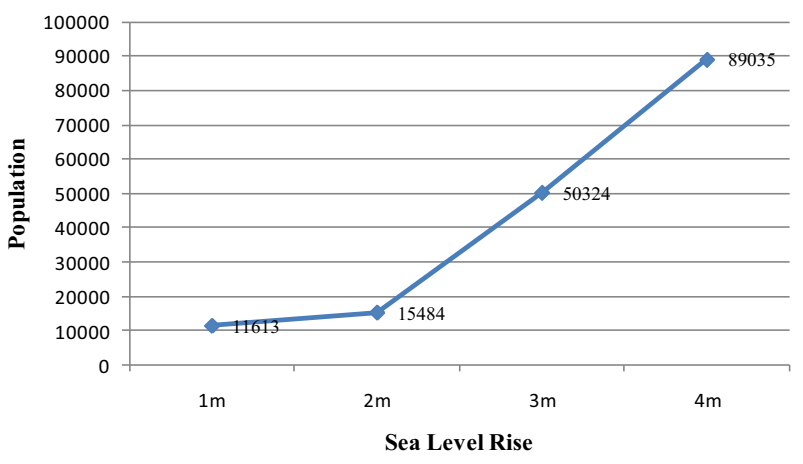

Fig. 4 Total surface area lost to sea level rise

Fig. 5 Neighbourhood divisions in Richmond, BC

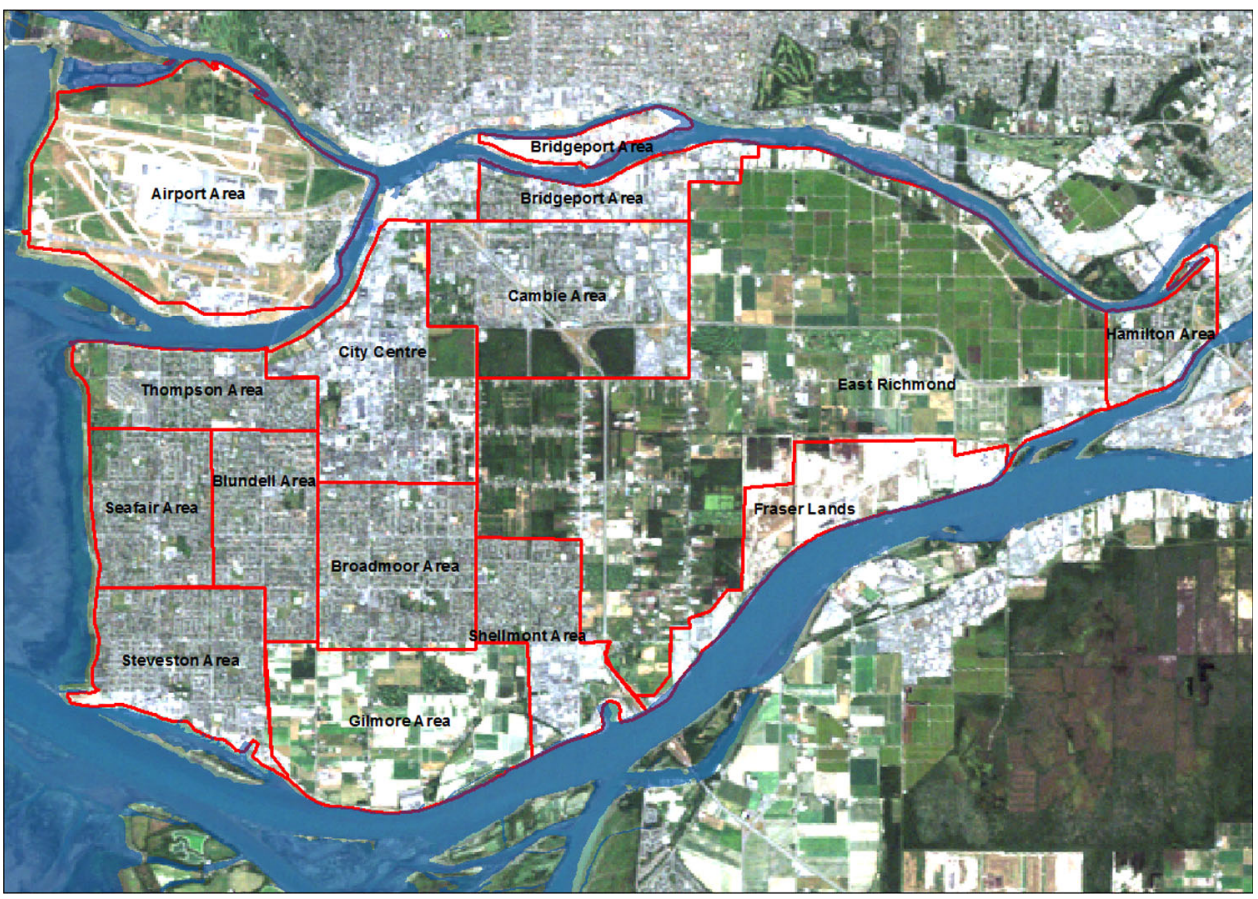

Affected Neighbourhoods (4m SLR)

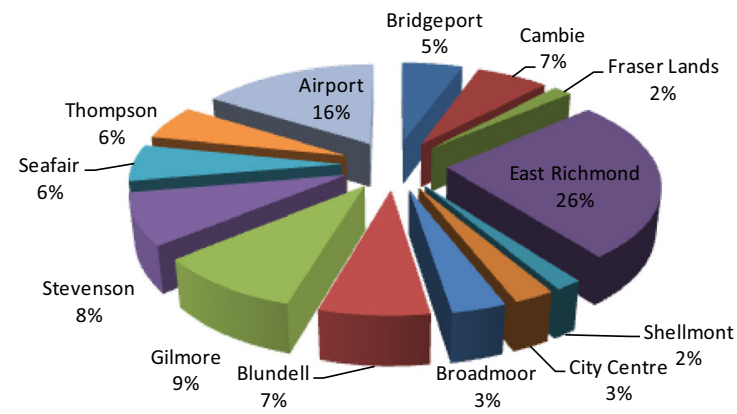

Affected Neighbourhoods (4m SLR)

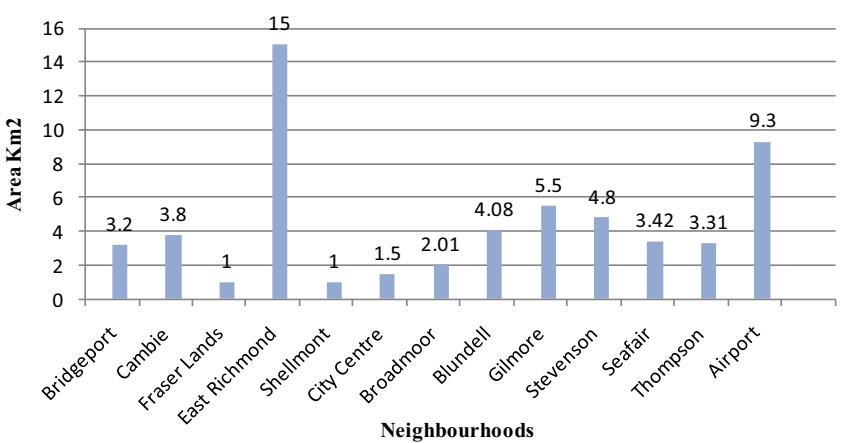

Fig. 6 Breakdown of impacted neighbourhoods in Richmond, BC 
SLR impact on Residential Areas

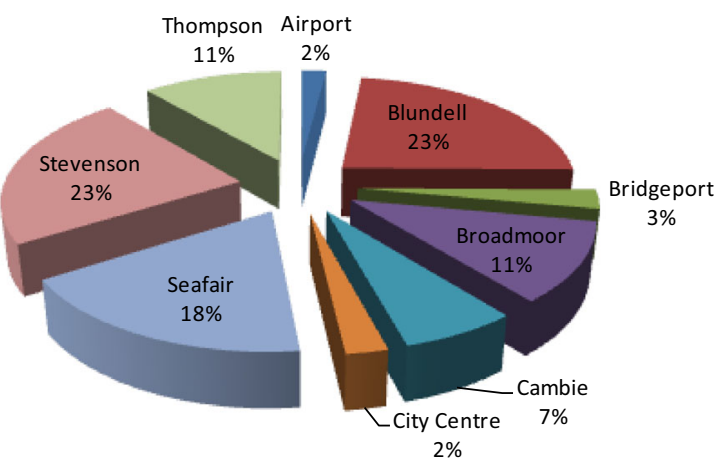

SLR impact on varios Neighbourhoods

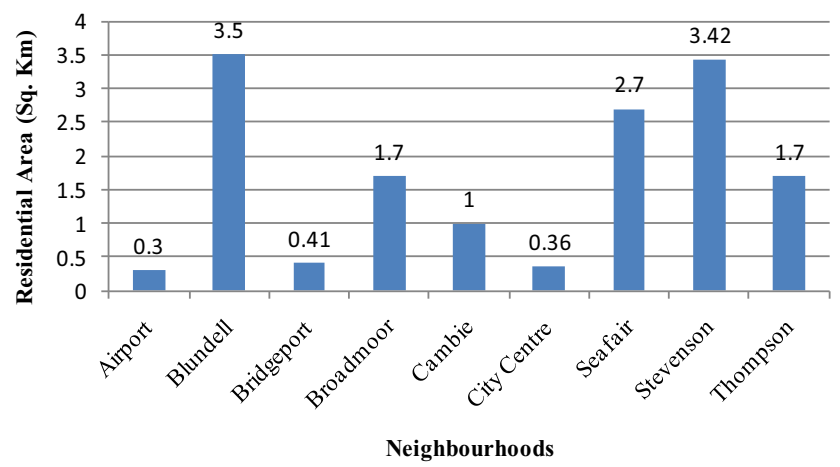

Fig. 7 Impact of sea level rise on residential areas on various neighbourhoods
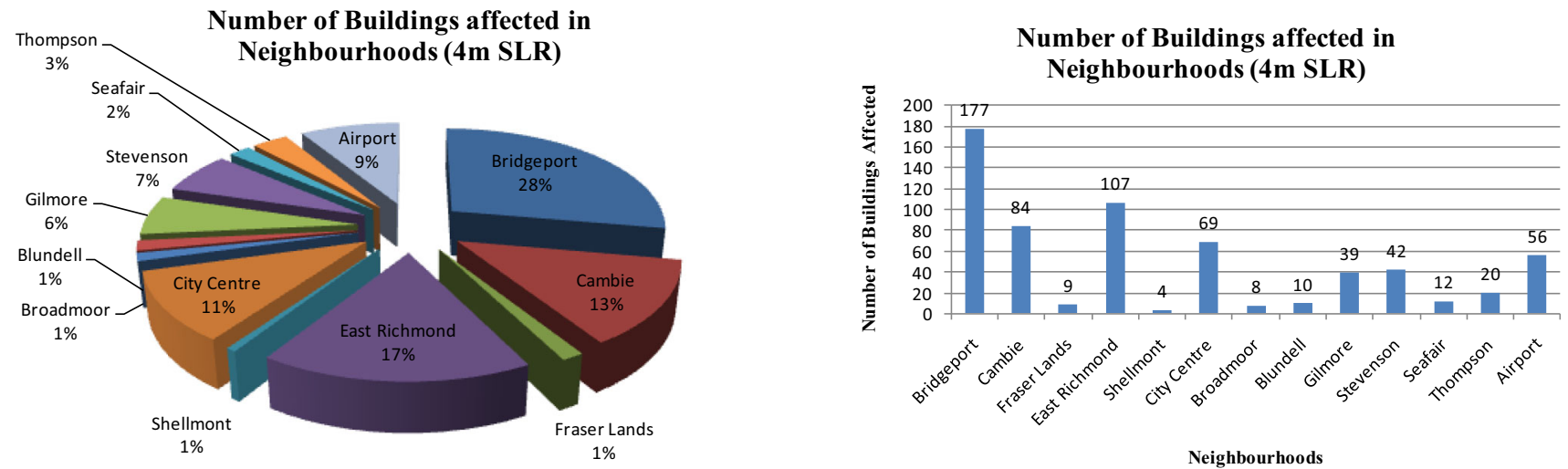

Fig. 8 Number of non-residential buildings affected due to sea level rise in various neighbourhoods

Table 9 Affect of sea level rise on population in various neighbourhoods

\begin{tabular}{lccc}
\hline Neighbourhoods & Total population & Population affected & \% of affected pop. \\
\hline Bridgeport & 2995 & 2408 & 80 \\
Cambie & 17,150 & 10,331 & 60 \\
City Centre & 38,610 & 4029 & 10 \\
Broadmoor & 22,350 & 7279 & 33 \\
Blundell & 17,500 & 15,313 & 88 \\
Stevenson & 24,105 & 20,610 & 86 \\
Seafair & 16,165 & 12,124 & 75 \\
Thompson & 15,450 & 12,507 & 81 \\
Airport & 770 & 770 & 100 \\
\hline
\end{tabular}

affected. The impact on road network increased from 102 to $242 \mathrm{~km}$. The hardest hit neighbourhoods in terms of surface area lost are East Richmond (9.6 sq. km), Airport (7.9 sq. km), Gilmore (5.4 sq. km), and Stevenson (3.5 sq. $\mathrm{km})$. The other partially affected neighbourhoods include Cambie, Bridgeport, Fraser Lands, Broadmoor, Blundell, Seafair, and Thompson, (Table 9). The most affected residential areas are in Blundell and Stevenson neighbourhoods with 2.7 and 2.5 sq. $\mathrm{km}$ areas affected respectively.
Bridgeport neighbourhoods lost 106 buildings, highest compared to other neighbourhoods followed by East Richmond (66), Stevenson (37), Airport (34), Cambie (32), City Centre (27), and Gilmore (19). (Table 10).

\section{$4 m$ sea level rise scenario}

If this scenario occurred, it would be catastrophic for the City of Richmond, as agriculture production would decline 
Table 10 Number of dwellings affected by sea level rise in various neighbourhoods

\begin{tabular}{lccc}
\hline Neighbourhoods & Total Dwellings & \# of affected Dwellings & \% of affected dwellings \\
\hline Bridgeport & 850 & 680 & 80 \\
Cambie & 5105 & 3063 & 60 \\
City Centre & 16,535 & 1653 & 10 \\
Broadmoor & 7460 & 2461 & 33 \\
Blundell & 5650 & 4972 & 88 \\
Stevenson & 8915 & 7666 & 86 \\
Seafair & 5580 & 4185 & 75 \\
Thompson & 5250 & 4252 & 81 \\
Airport & 290 & 290 & 100 \\
\hline
\end{tabular}

\section{$\%$ of Population affected in each} Neighbourhood

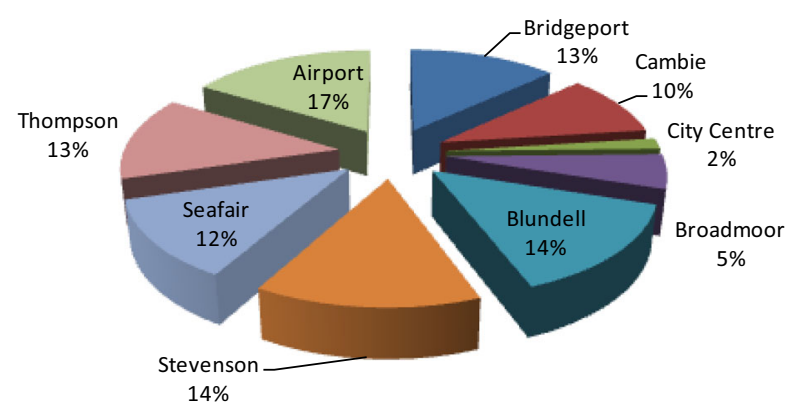

Fig. 9 Effect of sea level rise on population in various neighbourhoods

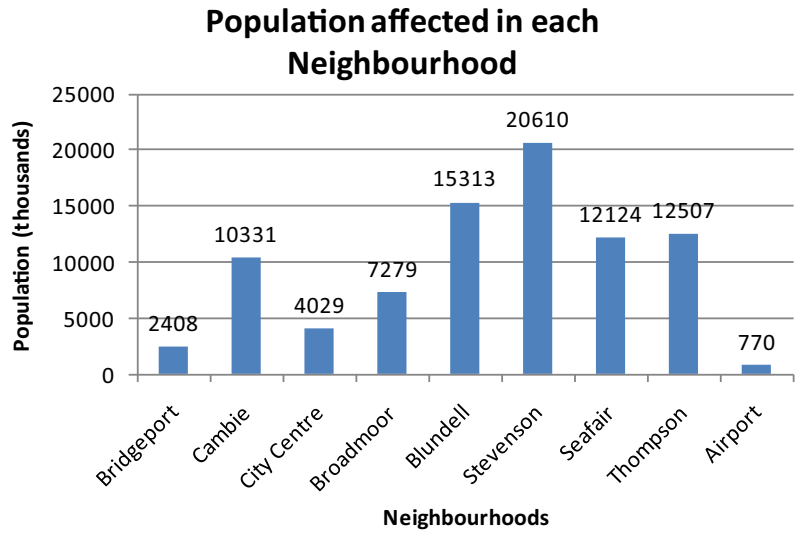

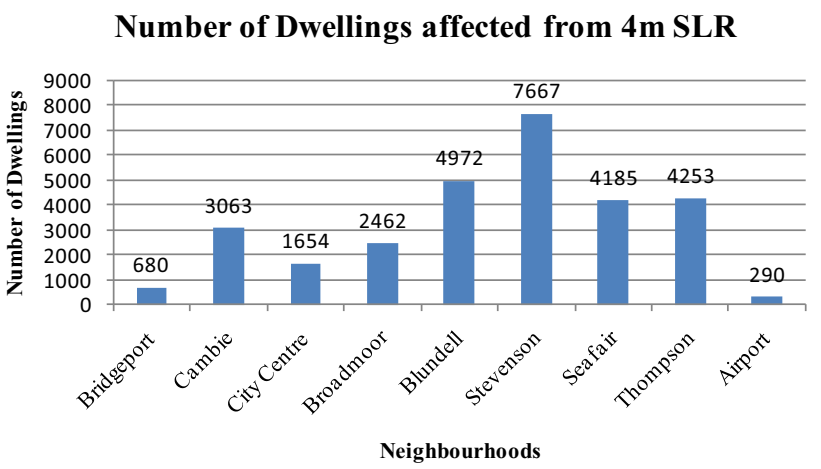

Fig. 10 Number of dwellings affected by sea level rise in various neighbourhoods

in East Richmond, coastal populations would be displaced, and the infrastructure of the city would be strongly affected. This scenario inundates $60 \mathrm{sq}$. $\mathrm{km}$ surface area representing $46 \%$ of the total land area. The impact on the Road Network is increased to $462 \mathrm{~km}$ and 637 buildings which account for $68 \%$ of the total buildings in Richmond are affected (Table 10). Out of these 637 affected buildings, two community centres, one court house, twenty-six educational facilities, one fire station, two hospitals, and seven industrial buildings are affected.
In addition $15 \mathrm{sq} . \mathrm{km}$ of residential area is inundated representing $55 \%$ of the total area; with this impact-increase on the residential areas, the population affected jumps to 89,035 people. The highest number of people are affected in Stevenson neighbourhood $(20,610)$, followed by Blundell $(15,313)$, Thompson $(12,507)$, and Seafair $(12,124)$, the remaining numbers of the affected population is shown in Table 11.

At this scenario all neighbourhoods are affected except for Hamilton; in terms of land East Richmond lost the highest surface area compared to other neighbourhoods, followed by Airport, Gilmore, and Stevenson, losing 15, 9.3, 5.5, and 4.8 sq. $\mathrm{km}$ respectively (See Table 10 for details). However, in terms of percentage, the hardest hit neighbourhood is Blundell, losing $89 \%$ of its total area followed by Stevenson ( $83 \%$ ), Thompson (79 \%), Seafair $(76 \%)$, and Bridgeport (73\%). The impact on other neighbourhoods is shown in Table 11.

Moreover, at 4-m sea level rise all the residential areas in Richmond are affected with Blundell neighbourhood losing the greatest area ( $3.5 \mathrm{sq} . \mathrm{km})$ followed by Stevenson (3.42 sq. km), and Seafair (2.7 sq. km). See Table 7 for impact on other neighbourhoods. In terms of percentage of residential area lost, Airport lost all of it residential area, 
Blundell lost $88 \%$, and Stevenson lost $86 \%$ of the residential area (Table 12). As more residential areas are inundated, more people will be displaced and more dwellings will be under water (Table 12).

\section{Visualizing of the impact of sea level rise}

Various methods of geographic visualization are beneficial for depicting both the propagation of potential inundation as well as the probable impact of sea level rise on the natural and built-up environments (Li et al. 2009). Because different audiences may prefer different methods of data representation, multiple visualization techniques were explored and were used to convey the geographic dimensions of sea level rise in Richmond, BC. For those wanting to use the information for analytical and statistical purposes, ArcGIS was used to generate statistical results to analyze and present the impact on socio-economic factors such as population, dwellings, residential areas, road net work, and surface areas. To depict the possible spatial propagation of potential inundation, map animations were developed using Google Earth and MicroDEM. These animations stimulated the extent of sea level rise over Richmond.

There is a limited scholarly literature specifically related to sea level rise and its impact on the coastal areas of Richmond. The following study, therefore, raises some pertinent issues related to the sea level rise and its impacts. The principal focus of the analyses in this paper was to assess the extent and probable impact of sea level rise and to visually and statistically present the results. Based on the hierarchy of priorities presented by Jones et al. (1999) for climate change mitigation/adaptation measures, the following study dealt with the first two priorities.

Table 11 Impact of $4 \mathrm{~m}$ sea level rise on the surface area of various neighbourhoods

\begin{tabular}{llll}
\hline Neighbourhoods & Total area $\left(\mathrm{km}^{2}\right)$ & $4 \mathrm{~m}$ SLR & Area lost $(\%)$ \\
\hline City Centre & 8.1 & 1.5 & 19 \\
Fraser lands & 5.3 & 1 & 19 \\
Shellmont & 4.7 & 1 & 21 \\
Broadmoor & 6.3 & 2.01 & 32 \\
East Richmond & 37.6 & 15 & 40 \\
Cambie & 9.1 & 3.8 & 42 \\
Gilmore & 9.2 & 5.5 & 60 \\
Airport & 14 & 9.3 & 66 \\
Bridgeport & 4.4 & 3.2 & 73 \\
Seafair & 4.5 & 3.42 & 76 \\
Thompson & 4.2 & 3.31 & 79 \\
Stevenson & 5.8 & 4.8 & 83 \\
Blundell & 4.6 & 4.08 & 89 \\
\hline
\end{tabular}

Through analyses, it is clear that sea level rise in Richmond will affect the range of different areas and infrastructure. Beaches, estuaries, and creeks will most likely be affected, followed by floodplains and tidal areas. Additionally, valuable infrastructure such as road network, residential and non-residential buildings, and utilities will also be damaged. As a result of an impact on infrastructure, many people will be displaced or forced to move out to other safe locations.

Although there are few limitations in the study, nevertheless, the results can be used by the local government and stakeholders for further research. Additionally, the findings can be valuable for the local and provincial government to effectively cope with the impacts of sea level rise and to use the results for mitigation and adaptation measures. The local government can take several initiatives to minimize the impact of sea level rise. Some of these initiatives can include passing a law that will prevent further development and re-development in the low-lying regions along the coast of the city, educate the public through intensive public awareness campaigns; this can be effective through media such as television, radio, and social network websites. Additionally construct levees, bulkheads, raise development in flood-prone areas, and finally, allocate funds for strategic planning related to the impacts of sea level rise as illustrated in Figs. 11 and 12.

\section{Conclusions}

The main objective of this study was to assess and analyze the impact of sea level rise on the city of Richmond. The study was undertaken in a systematic manner and was initiated by understanding the natural atmosphere, greenhouse effect, anthropogenic activities and its effects on the natural environment, historical temperature change and projection, and the link between high temperatures and sea level rise. Moreover, several studies were explored related to the use of GIS and sea level rise impact assessment were explored.

In order to analyze the sea level rise impact and assess the damage, a model of inundated areas was created. This model in the form of four different sea level rise scenarios was then overlaid on various GIS layers to assess the impact on the surface area of the city, the surface area of various neighbourhoods, road network, residential areas, the number of buildings, the number of dwellings, and population. The population and the dwellings data were in the form of non-spatial data and therefore, the impact on these two factors were approximated using Eqs. 2 and 3.

The results were produced by using several different approaches. To quantify the impact, Zonal Statistics Tool 
Table 12 Sea level rise impact on residential areas in various neighbourhoods

\begin{tabular}{llll}
\hline Neighbourhoods & Total Residential Area $\left(\mathrm{km}^{2}\right)$ & $4 \mathrm{~m}$ SLR & Percentage of Area Lost $\left(\mathrm{km}^{2}\right)$ \\
\hline City Centre & 3.45 & 0.36 & 10 \\
Broadmoor & 5.22 & 1.7 & 33 \\
Cambie & 1.66 & 1 & 60 \\
Airport & 0.3 & 0.3 & 100 \\
Bridgeport & 0.51 & 0.41 & 80 \\
Seafair & 3.6 & 2.7 & 75 \\
Thompson & 2.1 & 1.7 & 81 \\
Stevenson & 4 & 3.42 & 86 \\
Blundell & 4 & 3.5 & 88 \\
\hline
\end{tabular}
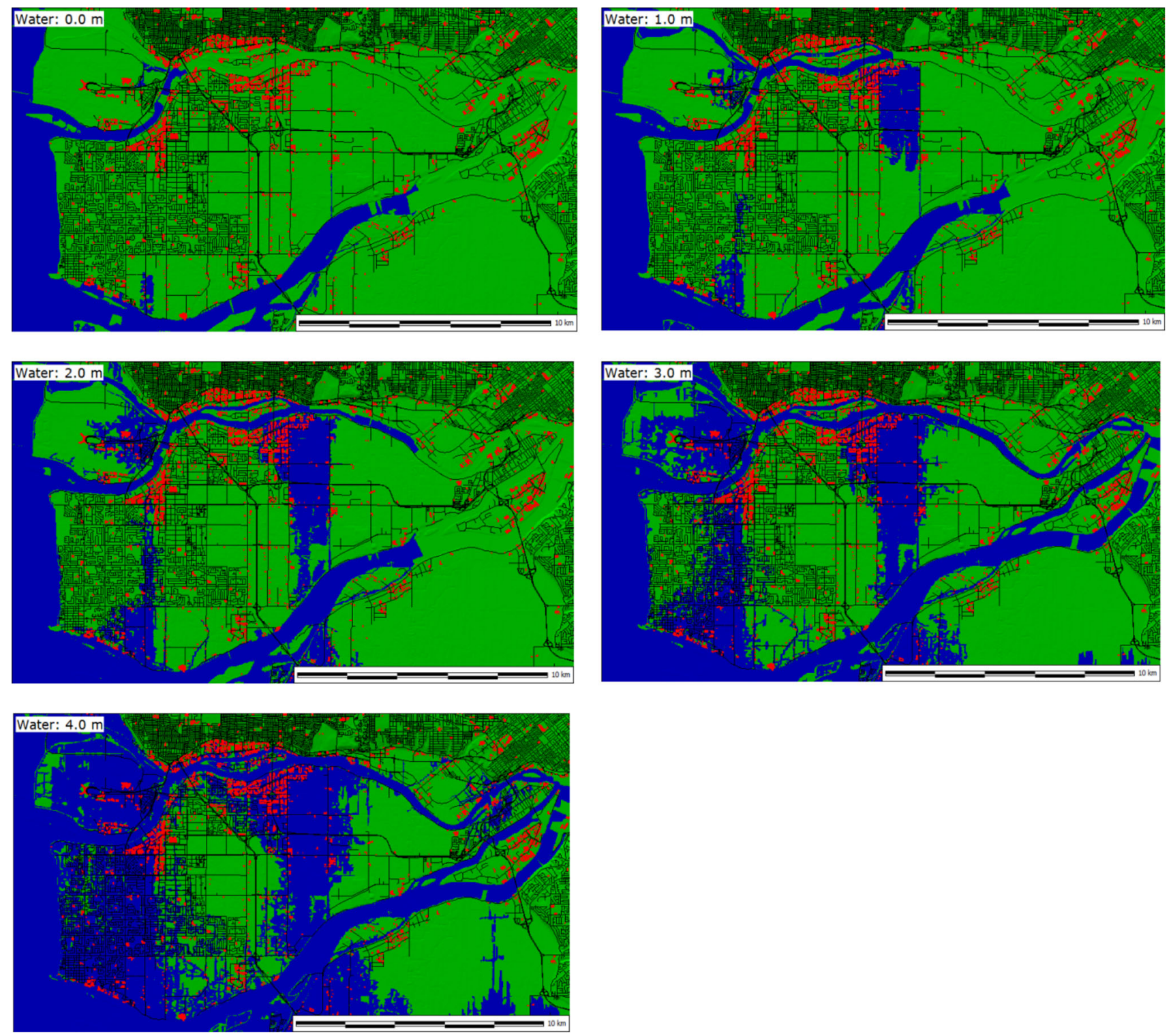

Fig. 11 Still-images from MicroDEM simulation showing various scenarios 


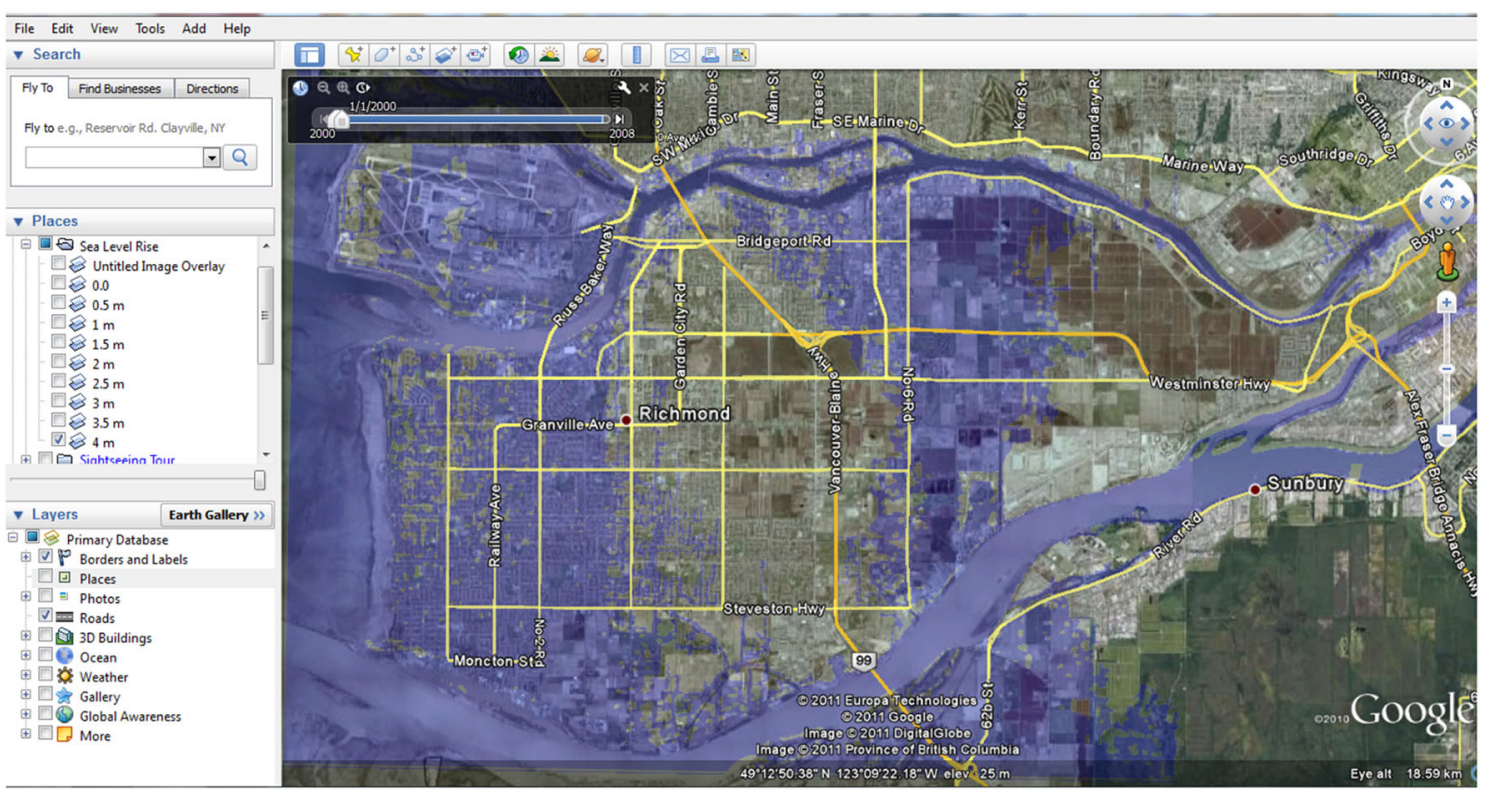

Fig. 12 Potentially inundated areas at $4 \mathrm{~m}$ displayed in google earth simulation

in ArcGIS was used to derive tables and statistical information. Using the data from these tables, several graphs were also generated in Excel. Moreover, two visualization methods were used in the research; in the first method, static maps were generated to visually represent the impact and extent of sea level at different scenarios. In the second method, interactive visualization simulations were generated using MicroDEM and Google Earth. These simulations depicted spatial propagation of sea level rise at different scenarios.

\section{References}

Al-Jeneid S, Bahnassy M, Nasr S, Raey M (2008) Vulnerability assessment and adaptation to the impacts of sea level rise on the Kingdom of Bahrain. Mitig Adapt Strat Glob Change 13:87-104

Anthoff D, Nicholls R, Tol RAV (2006) Global and regional exposure to large rises in sea-level: a sensitivity analysis. Tyndell Centre for Climate Change Research

Azaz LK (2010) Using remote sensing and GIS for damage assessment after flooding, the case of Muscat, Oman after. International Conference on Urban Planning (pp. 879-880). Vienna: REAL CORP

Bjorke J, Nilsen S (2004) Examination of a constant-area quadrilateral grid in the representation of global digital elevation models. Int J Geogr Info Sci GIS 18:653-664

Dasgupta S, Laplante B, Meisner C, Wheeler D, Yan J (2009) he impacts of sea level rise in developing countries: a comparative analysis. Clim Change 93:379-388

El-Nahry A, Doluschitz R (2010) Climate change and its impacts on the coastal zone of the Nile Delta. Egypt Environ Earth Sci 59:1497-1506

Gravelle G, Mimura N (2008) Vulnerability assessment of sea-level rise in Viti Levu, Fiji Islands. Sustain Sci 3:171-180
Jones P, Parker D, Martin S, Rigor I (1999) Surface air temperature and its variations over the last 150 years. Rev Geophys 37:173-199

Kuleli T, Senkal O, Erdem M (2008) National assessment of sea level rise using topographic and census data for Turkish coastal zone. Environ Monit Assess 156:425-434

Li X, Rowley R, Kostelnick J, Braaten D, Meisel J, Hulbutta K (2009) GIS analysis of global impacts from sea level rise. Photogrammetric Eng Rem Sens 75:807-818

Longley P (2005) Geographic information systems and science. Wiley

Marfai M, King L (2008) Potential vulnerability implications of coastal inundation due to sea level rise for the coastal zone of Semarang city, Indonesia. Environ Geol 54:1235-1245

McGranahan G, Balk D, Anderson B (2007) the rising tide: assessing the risks of climate change and human settlements in low elevation coastal zones. Environ Urbanization 19:17-37

Natesan U, Parthasarathy A (2010) The potential impacts of sea level rise along the coastal zone of Kanyakumari District in Tamilnadu, India. J Coastal Conserv 14:207-214

Nicholls R (2002) Analysis of global impacts of sea-level rise: a case study of flooding. Phys Chem Earth 27:1455-1466

Nicholls R (2004) Coastal flooding and wetland loss in the 21st century: changes under the SRES climate and socio-economic scenarios. Glob Environ Change 14:69-86

Nicholls R, Tol R (2006) Impacts and responses to sea-level rise: a global analysis of the SRES scenarios over the twenty-first century. Philosophical Trans Royal Soc Ser A Math Phys Eng Sci 364:1073-1095

Nicholls R, Hoozemans F, Marchand M (1999) Increasing flood risk and wetland losses due to global sea-level rise: regional and global analyses. Glob Environ Change 9(1):69-87

Richmond C. o. (2009) Agriculture hot facts. The city of Richmond

Tol R, Bohn M, Downing T, Guillerminet M-L, Hizsnyik E, Kasperson $\mathrm{R}$ et al (2006) Adaptation to $5 \mathrm{~m}$ of sea level rise. J Risk Res 9:467-482

Weiss JL, Overpeck JT (2003) Climate change and sea level. University of Arizona. http://www.geo.arizona.edu/dgesl/ research/other/climate_change_and_sea_level/sea_level_rise/ sea_level_rise.htm. Accessed 26 March 2009 